\title{
Relationship between serum survivin levels before radiotherapy and clinical response in patient with stage iib cervical carcinoma
}

\begin{abstract}
Background: Cervical carcinoma is the main malignant disease that causes death in women. Radiation is a therapy for cervical carcinoma. Radiation will induce apoptosis in carcinoma cells. Survivin as anti apoptosis will inhibit cervical carcinoma response to radiotherapy. For this reason, it is necessary to conduct a study that compares survivin levels in cervical carcinoma patients before radiotherapy with clinical response.

Method: This study is an observational design with analytical cohort studies. The survivin serum level and mass size of 30 stage IIB cervical carcinoma patients were measured before radiotherapy, then the size of the mass was measured again after the patient completing radiotherapy. Mass size before and after radiotherapy is compared to determine the patient's clinical response to radiotherapy.The study was conducted at the Gynecology Oncology Clinic, Radiotherapy Department and Clinical Pathology Laboratory of Hasan Sadikin Hospital in January to July 2019.

Result: Subjects with lower mean of survivin level, $111,789 \pm 2.47 \mathrm{pg} / \mathrm{mL}$ produced a complete clinical response. Whereas subjects with a higher survivin level, $502,689 \pm 1.26 \mathrm{pg} /$ $\mathrm{mL}$ produced a partial clinical response. From the result of the T Test it was found that the mean of survivin serum levels were significant with $\mathrm{p}$ value of 0.029 .
\end{abstract}

Conclusion: The higher the survivin level before radiotherapy, the worse the clinical response to radiotherapy in patients with stage IIB cervical carcinoma.
Volume II Issue 5 - 2020

\author{
Romy Ade Putra, Hadi Susiarno, Ali Budi \\ Harsono, Adji Kusumadjati \\ Department of Obstetric and Gynecology, Padjajaran University, \\ Hasan Sadikin Hospital, Indonesia
}

Correspondence: Romy Ade Putra, Department of Obstetric and Gynecology, Padjajaran University, Hasan Sadikin Hospital, Bandung, Indonesia, Email romydeputra@gmail.com

Received: July 23, 2020 | Published: September 08, 2020

Keywords: survivin, radiotherapy, clinical response, cervical carcinoma

Abbreviations: IAP, inhibitor of apoptosis protein; EDTA, ethylenediaminetetraacetic acid; RSHS, clinical pathology laboratory of the hasan sadikin hospital

\section{Introduction}

Radiation is a therapy for cervical carcinoma. Radiation will cause carcinoma cell death through induction of apoptosis. Cells that undergo apoptosis will be broken down into small pieces called apoptotic bodies and will then be phagocytosized. Apoptotic events can be inhibited by apoptotic inhibiting proteins. One of the apoptotic inhibiting proteins expressed in squamous cell carcinoma, determining the degree of atypia of carcinoma cells and increasing resistance to therapy is survivin. Survivin is an inhibitor of apoptosis protein (IAP) which plays an important role in the regulation of apoptosis and cell division. Survivin's expression was found to be very low in normal adult tissue but his expression was high in tumor tissue. If the level of survivin is too high then the cell will continue to differentiate, resulting in uncontrolled cell growth and resistance to therapy. Thus the success of radiotherapy in cervical carcinoma will be influenced by survivin levels. For this reason, it is necessary to conduct a research that proves the relationship between survivin levels and the patient's clinical response to radiotherapy. ${ }^{1-28}$

\section{Method}

This research was an observational study with an analytical cohort study design. Serum survivin levels and mass size of 30 stage IIB cervical carcinoma patients were measured before radiotherapy, then mass size were measured again after the patient completing radiotherapy. Mass size before and after radiotherapy are compared to determine the patient's clinical response to radiotherapy.

The sampling technique was randomized sampling, where each group of dependent variables was taken randomly.

Blood that has been taken with a syringe is immediately inserted into a sterile tube containing ethylenediaminetetraacetic acid (EDTA). Blood from the superficial vein (mediana cubiti) of $3 \mathrm{~mL}$ was centrifuged at a rate of 2000 rotations per minute (rpm) for 15 minutes to obtain the serum. The serum obtained is then put into a microtube and stored in an icebox.

The serum obtained was immediately sent by researchers to the Clinical Pathology Laboratory of the Hasan Sadikin Hospital (RSHS) for a survivin examination with the Elabscience ${ }^{\circledR}$ Human Surv ELISA kit.

The study was conducted at the Gynecology Oncology Clinic of dr. Hasan Sadikin Hospital Bandung in January-July 2019. Examination of serum survivin levels was carried out at the Clinical Pathology Laboratory of Hasan Sadikin Hospital.

\section{Result}

The age of the subjects is between 36 to 70 years old with an average age of 52.66 years old. The lowest serum survival rate was $9.84 \mathrm{pg} / \mathrm{mL}$ and the highest level was $591.01 \mathrm{pg} / \mathrm{mL}$. Pearson correlation test was 
performed, the $r$ value was 0.187 and the $p$ value was 0.32 so it can be said that the two variables were not linearly related (Table 1 ).

Table I Age relatedness of serum survivin rates

\begin{tabular}{llll}
\hline Value & $\begin{array}{c}\text { Age } \\
\text { (Years) }\end{array}$ & $\begin{array}{l}\text { Survivin } \\
(\mathbf{p g} / \mathrm{mL})\end{array}$ & Correlation test \\
\hline Minimum & 36 & 9,84 & $\mathrm{r} 0,187$ \\
Maximum & 70 & 591,01 & $\mathrm{p} 0,32$ \\
Mean & 52,66 & 175,67 & \\
\hline
\end{tabular}

From Table 2 it can be seen that the smallest tumor size is $3 \times 3 \times 2 \mathrm{~cm}$ and the largest size is $8 \times 7 \times 6 \mathrm{~cm}$. After a correlation test with serum survivin levels, a significant relationship was found. Tumor size is directly proportional to serum survivin levels with $r$ values of 0.42 and $p$ value of 0.021 .

Table 2 Relationship of tumor size before radiotherapy with survivin serum levels

\begin{tabular}{llll}
\hline Value & Tumor size $(\mathbf{c m})$ & Survivin $(\mathrm{pg} / \mathbf{m L})$ & $\begin{array}{l}\text { Correlation } \\
\text { test }\end{array}$ \\
\hline Minimum & $3 \times 3 \times 2$ & 9,84 & $\mathrm{r} 0,42$ \\
Maximum & $8 \times 7 \times 6$ & 591,01 & $\mathrm{P} 0,021$ \\
Mean & 67,31 & 175,67 & \\
\hline
\end{tabular}

From this table it can be seen that patients who have lower serum survivin levels with an average of $111.789 \pm 2.47 \mathrm{pg} / \mathrm{mL}$ before radiotherapy produce a complete response. Whereas patients who had higher serum survivin levels with an average of $502,689 \pm 1.26 \mathrm{pg} / \mathrm{mL}$ produced a partial clinical response. From the results of statistical analysis, the mean difference in serum survivin levels before radiotherapy in patients with complete and partial clinical responses has a $p$ value of 0.029 (Table 3 ).

Table 3 Comparison of serum survivin levels before radiotherapy and clinical response of patients with stage IIB cervical carcinoma

\begin{tabular}{lll}
\hline Clinical response & $\begin{array}{l}\text { Mean of serum survivin } \\
\text { value }(\mathbf{p g} / \mathrm{mL})\end{array}$ & $\mathbf{p}$ \\
\hline Complete & $\mathrm{I} \mathrm{I} 1,789 \pm 2,47$ & 0,029 \\
Partial & $502,689 \pm 1,26$ & \\
\hline
\end{tabular}

\section{Discussion}

In this study stage IIB cervical carcinoma patients undergoing radiotherapy were measured for serum survivin levels. Serum survivin levels obtained differ in each patient. The lowest level of survivin obtained was $9.84 \mathrm{pg} / \mathrm{mL}$ and the highest level was $591.01 \mathrm{pg} / \mathrm{mL}$. Complete clinical response was obtained in lower mean of survivin levels, $111,789 \pm 2.47 \mathrm{pg} / \mathrm{mL}$. In this group, cervical carcinoma masses were no longer found post-radiotherapy. In the research subjects who had higher mean survivin levels, 502,689 $\pm 1.26 \mathrm{pg} / \mathrm{mL}$, produced a partial response. In this group there is a reduction in mass size after radiotherapy. According to WHO criteria with bidimensional measurements, a reduction in tumor mass size of at least $50 \%$ from the size before radiation is called a partial response, while according to RECIST criteria with unidimensional measurements, a reduction in mass size of at least $30 \%$ from the initial mass before radiation is called a partial response. ${ }^{29}$ James et al . first proposed unidimensional measurement of 14 different retrospective analysis studies. The results of the analysis stated that bidimensional and unidimensional measurement results did not change the results in each of these studies. Thus in this study the RECIST criteria were used to assess the clinical response of patients after radiotherapy.

From 30 subjects, there were 28 subjects with complete responses and 2 subjects with partial responses. Both subjects with partial response had higher survivin levels compared to 28 other subjects. These results are in accordance with the mechanism of survivin as an anti-apoptosis which will inhibit apoptosis in radiation so that decreases the response to radiation. ${ }^{30-35}$

Besides being determined by the degree of atypia of cancer cells, survivin expression can also be influenced by other factors such as infection, inflammation and diabetes. In a study conducted on 70 research subjects who were divided into 3 groups, namely group I as a control as many as 20 subjects, group II with Hepatitis C infection as many as 20 subjects and group III with hepatocellular carcinoma as many as 30 subjects obtained a significant increase in survivin expression in group II compared with the control group $(p=0.039) .{ }^{36}$ In the inflammatory process, survivin is known to be a marker to differentiate Rheumatoid Arthritis patients from the control group. In a study conducted on 132 rheumatoid arthritis patients and 82 controls, levels of survivin were associated with urokinase, a plasminogen activator expressed in joint inflammation. ${ }^{37}$

In this study other factors that cause an increase in survivin levels were not taken into account in the measurement of survivin levels because this study only looked at the relationship between serum survivin levels in each subject and clinical response after radiotherapy. So it was hypothesized that subjects who had high serum survivin levels even if caused by other factors would still produce a poor response to radiotherapy. From the results of data analysis, a significant average difference was obtained. Research subjects who had higher survivin levels produced a poor response to radiotherapy.

\section{Conclusion}

The higher serum survivin levels before radiotherapy, the worse the clinical response to radiotherapy in patients with stage IIB cervical carcinoma.

\section{Acknowledgments}

None.

\section{Funding}

None.

\section{Conflicts of interest}

All authors declare that they have no competing interests.

\section{References}

1. Cheng K-y, Wang Z-1, Gu Q-y, et al. Survivin overexpression is associated with aggressive clinicopathological features in cervical carcinoma: a meta-analysis. PLoS One. 2016;11(10):e0165117.

2. Caela Miller JCE. Cervical and vaginal cancer. In: Berek JS, editor. Berek and Novak's Gynecology. 15th edn. Philadelphia: Wolters Kluwer; 2012.

3. Lasut E, Rarung M, Suparman E. Characteristics of cervical cancer patients by BLU RSUP Prof. Dr. RD Kandou. e-CliniC; 2015;3(1).

4. Tamara L Callahan ABC. Cervical cancer. 6th edn. Philadelphia: Wolters Kluwer; 2013. 
5. Khan Z, Khan AA, Yadav $\mathrm{H}$, et al. Survivin, a molecular target for therapeutic interventions in squamous cell carcinoma. Cell Mol Biol Lett. 2017;22(1):8

6. Pincelli C, Marconi A. Keratinocyte stem cells: friends and foes. $J$ Cell Physiol. 2010;225(2):310-315.

7. Fukuda S, Pelus LM. Survivin, a cancer target with an emerging role in normal adult tissues. Mol Cancer Ther. 2006;5(5):1087-1098.

8. Shojaei F, Yazdani-Nafchi F, Banitalebi-Dehkordi M, et al. Trace of survivin in cancer. 2019;28(4):365-372.

9. Sah N, Khan Z, Khan G, et al. Structural, functional and therapeutic biology of survivin. Cancer Lett. 2006;244(2):164-171.

10. Altieri DC. Survivin in apoptosis control and cell cycle regulation in cancer. Prog Cell Cycle Res. 2003;5:447-452.

11. Hreshchyshyn MM, Aron BS, Boronow RC, et al. Hydroxyurea or placebo combined with radiation to treat stages IIIB and IV cervical cance confined to the pelvis. Int J Radiat Oncol Biol Phys. 1979;5(3):317-322.

12. Park JO, Lee SI, Song SY, et al. Measuring response in solid tumors: comparison of RECIST and WHO response criteria. Jpn J Clin Oncol. 2003;33(10):533-537.

13. Rödel C, Haas J, Groth A, et al. Spontaneous and radiation-induced apoptosis in colorectal carcinoma cells with different intrinsic radiosensitivities: survivin as a radioresistance factor. Int J Radiat Oncol Biol Phys. 2003;55(5):1341-1347.

14. Rasjidi I. Cervical cancer epidemiology. Indonesian Journal of cancer. 2009;3(3).

15. Alberts B. Membrane transport of small molecules and the electrical properties of membranes. Mol Biol Cell. 2002:615-657.

16. Cooper GM, Hausman RE. The cell: Molecular approach. Edisi: Medicinska naklada; 2004.

17. Liu H-Q, Wang Y-H, Wang L-L, et al. P16INK4A and survivin: Diagnostic and prognostic markers in cervical intraepithelial neoplasia and cervical squamous cell carcinoma. Exp Mol Pathol. 2015;99(1):44-49.

18. Zhou X, Wang M. Expression levels of survivin, Bcl-2, and KAI1 proteins in cervical cancer and their correlation with metastasis. Genet Mol Res. 2015;14(4):17059-17067

19. Rodel F, Reichert S, Sprenger T, et al. The role of survivin for radiation oncology: moving beyond apoptosis inhibition. Curr Med Chem. 2011;18(2):191-199.

20. Capalbo G, Rödel C, Stauber RH, et al. The role of survivin for radiation therapy. Strahlenther Onkol. 2007;183(11):593-599.

21. Freier K, Pungs S, Sticht C, et al. High survivin expression is associated with favorable outcome in advanced primary oral squamous cell carcinoma after radiation therapy. Int J Cancer. 2007;120(4):942-946.

22. Rödel F, Hoffmann J, Distel L, et al. Survivin as a radioresistance factor and prognostic and therapeutic target for radiotherapy in rectal cancer. Cancer Res. 2005;65(11):4881-4887.
23. Kapp DS, Fischer D, Gutierrez E, et al. Pretreatment prognostic factors in carcinoma of the uterine cervix: a multivariable analysis of the effect of age, stage, histology and blood counts on survival. Int J Radiat Oncol Biol Phys. 1983;9(4):445-455.

24. Asanuma K, Moriai R, Yajima T, et al. Survivin as a radioresistance factor in pancreatic cancer. Jpn J Cancer Res. 2000;91(11):1204-1209.

25. Chakravarti A, Zhai GG, Zhang M, et al. Survivin enhances radiation resistance in primary human glioblastoma cells via caspase-independent mechanisms. Oncogene. 2004;23(45):7494.

26. Mita AC, Mita MM, Nawrocki ST, et al. Survivin: key regulator of mitosis and apoptosis and novel target for cancer therapeutics. Clin Cancer Res. 2008;14(16):5000-5005.

27. Altieri DC. Validating survivin as a cancer therapeutic target. Nature Reviews Cancer. 2003;3(1):46.

28. Rödel C, Grabenbauer GG, Papadopoulos T, et al. Apoptosis as a cellular predictor for histopathologic response to neoadjuvant radiochemotherapy in patients with rectal cancer. Int J Radiat Oncol Biol Phys. 2002;52(2):294 303

29. Therasse P, Arbuck SG, Eisenhauer EA, et al. New guidelines to evaluate the response to treatment in solid tumors. $J$ Natl Cancer Inst. 2000;92(3):205-216.

30. Sohaib S, Turner B, Hanson J, et al. CT assessment of tumour response to treatment: comparison of linear, cross-sectional and volumetric measures of tumour size. The British journal of radiology. 2000;73(875):1178-1184.

31. Trillet-Lenoir V, Freyer G, Kaemmerlen P, et al. Assessment of tumour response to chemotherapy for metastatic colorectal cancer: accuracy of the RECIST criteria. The British journal of radiology. 2002;75(899):903-908.

32. Kimura M, Tominaga T. Outstanding problems with response evaluation criteria in solid tumors (RECIST) in breast cancer. Breast Cancer. 2002;9(2):153-159

33. Werner-Wasik M, Xiao Y, Pequignot E, et al. Assessment of lung cancer response after nonoperative therapy: tumor diameter, bidimensional product, and volume. A serial CT scan-based study. International Journal of Radiation Oncology Biology Physics. 2001;51(1):56-61.

34. Yoshida S, Miyata Y, Ohtsu A, et al. Significance of and problems in adopting response evaluation criteria in solid tumor RECIST for assessing anticancer effects of advanced gastric cancer. Gastric Cancer. 2000;3(3):128-133.

35. El-Attar H, Kandil M, El-Kerm Y, et al. Comparison of serum survivin and alpha fetoprotein in Egyptian patients with hepatocellular carcinoma associated with hepatitis C viral infection. Asian Pac J Cancer Prev. 2010;11(4):897-903.

36. Andersson K, Svensson M, Erlandsson M, et al. Down-regulation of survivin alleviates experimental arthritis. J Leukoc Biol. 2015;97(1):135145 .

37. Liggins C, Orlicky D, Bloomquist L, et al. Developmentally regulated expression of survivin in human pancreatic islets. Pediatr Dev Pathol. $2003 ; 6(5): 392-327$ 